- FINANSE I PRAWO FINANSOWE.

- Journal of Finance and Financial Law

Grudzień/December 2019 • vol. 4(24): 49-65

http://dx.doi.org/10.18778/2391-6478.4.24.04

\title{
OTOCZENIE REGULACYJNE SEKTORA FINTECH \\ NA PRZYKŁADZIE DYREKTYWY PSD2 \\ I WYBRANYCH USTAW KRAJOWYCH
}

Oliwia Gawron

Wydział Ekonomiczno-Socjologiczny, Uniwersytet Łódzki

\begin{abstract}
Streszczenie
W dobie cyfryzacji instytucje finansowe coraz częściej współpracują z podmiotami FinTech w celu tworzenia innowacji produktowych. Jednak rynek finansowy nie zawsze jest przygotowany na to. W obliczu niewystarczających regulacji sektora FinTech konsumenci nie zawsze mogą mieć zagwarantowane bezpieczeństwo a same podmioty FinTech mogą nie zostać dopuszczone do uczestnictwa w rynku. Dlatego istotną kwestią są działania zmierzające do uregulowania ich działalności. Celem artykułu jest przedstawienie wybranych regulacji sektora oraz ocena czy obejmują one rynek w sposób wystarczający.
\end{abstract}

Słowa kluczowe: FinTech, regulacje prawne, PSD2, innowacje technologiczne.

JEL Class: G2, G28, K220. 


\section{WPROWADZENIE}

Postępujące zmiany technologiczne, takie jak rozpowszechnienie Internetu oraz wszechobecna cyfryzacja, sprawiły że zmienił się otaczający nas świat, a wraz z nim zmianom uległ rynek finansowy. Było to po części spowodowane faktem, iż w kontakcie $\mathrm{z}$ nowościami technologicznymi konsumenci odkryli nowe potrzeby oraz zrozumieli, że obecnie dostępne produkty finansowe nie są już w stanie ich w pełni zaspokoić. Natomiast instytucje finansowe dostrzegły, że wykorzystanie innowacji pozwoli na zwiększenie oferty, co w efekcie pozwoliło im na podjęcie konkurencji z pozostałymi uczestnikami rynku. Podmioty, które zdecydowały się na wykorzystanie powyższych możliwości zaczęły tworzyć komórki odpowiedzialne za inkorporację nowoczesnych technologii lub outsourcować proces do podmiotów trzecich, najczęściej innowacyjnych start-upów. W wyniku tych działań powstały produkty i jednostki zwane FinTech (Financial Technology), a w konsekwencji sektor o tej samej nazwie. Jednak innowacyjne produkty nie mogły być traktowane na równi $\mathrm{z}$ usługami świadczonymi przez licencjonowane podmioty, m.in. dlatego, iż sektor FinTech nie jest uregulowany w takim samym stopniu jak tradycyjny rynek finansowy. Chociaż instytucje ustawodawcze podejmują szereg starań mających zmienić ten stan rzeczy, nadal nie wszystkie aspekty działalności FinTech mają wyznaczone ramy prawne lub są one rozproszone pomiędzy poszczególne ustawy.

Celem artykułu jest przedstawienie otoczenia regulacyjnego sektora innowacji finansowych na przykładzie unijnej dyrektywy PSD2 oraz wybranych krajowych ustaw, m.in. Prawa Bankowego. Ma to na celu pomóc w zweryfikowaniu hipotezy badawczej, zgodnie z którą obowiązujące obecnie regulacje nie chronią w sposób wystarczający konsumentów raz podmioty typu FinTech.

\section{PRZEDSTAWIENIE SEKTORA FINTECH}

Obecnie nie istnieje jedna definicja pojęcia FinTech. Jest to po części spowodowane faktem, iż nie ma tylko jednego zastosowania tego określenia. Można je stosować zarówno do produktów finansowych, podmiotów je tworzących, jak i sektora, na którym owe działają, zaś w szerokim ujęciu można tak określić nawet sam proces wdrażania nowoczesnych rozwiązań w celu zwiększenia efektywności świadczonych usług oraz tworzenia nowej wartości dodanej. Jednak w literaturze najczęściej spotykane są definicje odnoszące się do podmiotów oraz ich sektora [Harasim i Mitręga-Niestrój 2018: 173].

Zgodnie z definicją przyjętą przez KNF pod pojęciem FinTech kryją się podmioty działające na pograniczu sektorów finansów oraz informatyki, utylizujące zdobycze obu dziedzin do tworzenia nowoczesnych usług finansowych 
[www2]. Dla porównania, według Szpringera jako podmioty FinTech uznaje się jednostki gospodarcze, których cechą charakterystyczną jest wykorzystywanie innowacji do tworzenia nowych usług i wzbogacania tych dotychczas oferowanych. Produkty przez nie oferowane, mimo licznych podobieństw, nie mogą być jednak uznawane jako identyczne względem tych oferowanych przez tradycyjnych uczestników rynku finansowego, czyli licencjonowane podmioty, co przyczynia się bezpośrednio do tworzenia luk prawnych, tak jak to ma miejsce w przypadku banków i para banków [Szpringer 2017: 9].

Powyższe definicje wskazują, iż podmioty FinTech mogą działać na wielu obszarach rynku finansowego. Często w literaturze spotykane są ogólne segmentacje lub takie, posiadające pewne uogólnienia.

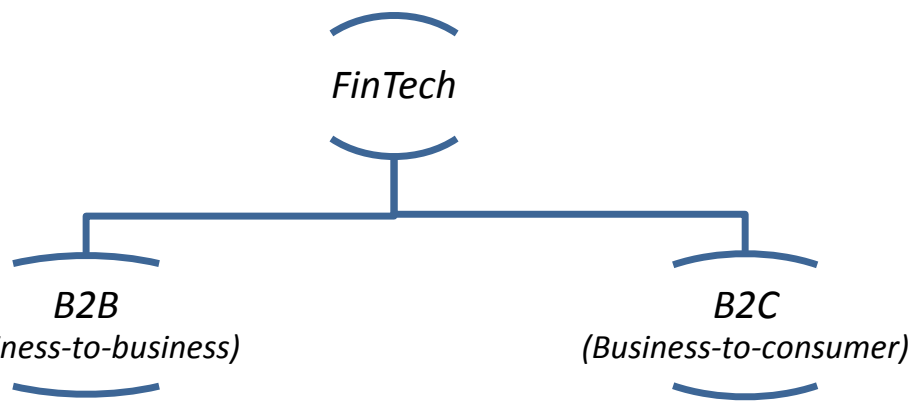

Schemat 1. Klasyfikacja sektora FinTech w oparciu o realizowane transakcje

Źródło: opracowanie własne na podstawie Micu i Micu [2016: 380-381].

Jedna z przykładowych klasyfikacji pokazuje podział wszystkich produktów FinTech na te, związane $\mathrm{z}$ transakcjami między podmiotami instytucjonalnymi (B2B Business-to-business) oraz operacjami między instytucjami a konsumentami (B2C Business-to-consumer). Pierwsze $\mathrm{z}$ nich skupiają się na wsparciu technologicznym, systemowym oraz procesowym, czyli m.in. zarządzaniu bazami danych klientów, przeprowadzaniu analiz rynku, dbaniu o cyberbezpieczeństwo, czy dostarczaniu usług typu compliance. Rozwiązania dedykowane interakcjom z klientem łączą zarówno technologie dostarczane przez inne podmioty, jak i usługi, które świadczy dana instytucja. Przykładowo, w przypadku banków takim rozwiązaniem będą aplikacje mobilne. Mimo swojej prostoty atutem powyższego podziału jest fakt, iż może być również stosowany do całego sektora innowacyjnych podmiotów, chociaż wiele z nich skupia się w swojej działalności tylko na jednym typie produktu, tak jak przykładowo firma PayPal, która oferuje usługi płatnicze zarówno przedsiębiorcom, jak i klientom indywidualnym [Micu i Micu 2016: 380-381]. 
Inną stosowaną klasyfikacją jest ta opierająca się o tradycyjną segmentację rynku finansowego. Zgodnie z nią sektor FinTech składa się z czterech segmentów - BankTech, InsurTech, WealthTech oraz RegTech [Pięta 2018: 250].

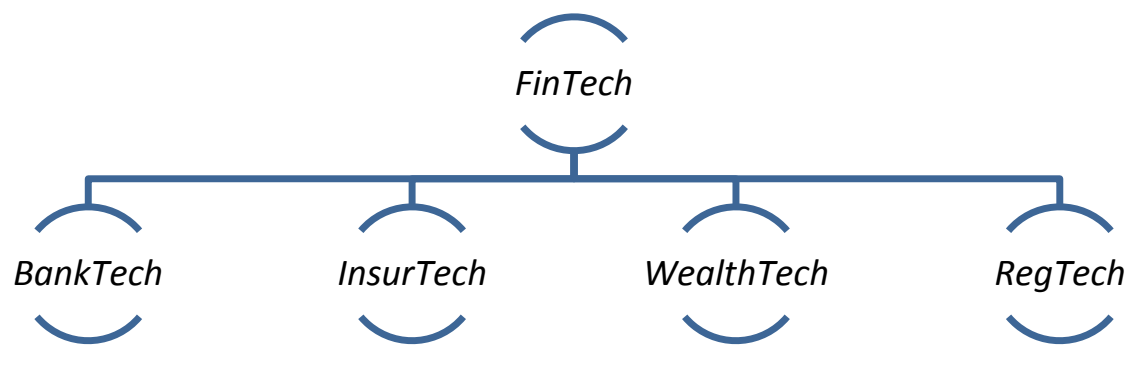

Schemat 2. Klasyfikacja sektora FinTech

Źródło: Pięta [2018: 250].

Podsektory BankTech i InsurTech są silnie związane z odpowiednio tradycyjnym sektorem bankowym oraz ubezpieczeniowym, a w ramach ich struktur znajdują się wszelkie innowacje produktowe, takie jak m.in. aplikacje mobilne, ale także usprawnienia dotyczące fizycznych, jak i zdalnych kanałów kontaktu z klientem. Biorąc pod uwagę, iż konsumenci są już zaznajomieni z pewną pulą produktów, na które w konsekwencji zawsze będzie popyt - głównie rachunki, kredyty i lokaty, banki postanowiły skoncentrować się na budowaniu relacji z odbiorcami. Wynikiem tego było wprowadzenie nowych kanałów komunikacji, będących w niektórych przypadkach również postrzegane jako usługi, m.in. placówki bankomatowe, zautomatyzowane centra telefoniczne (call center), bankowość internetowa oraz mobilna, pozwalające na wykonywanie transakcji bez potrzeby wychodzenia z domu [Baszyński 2016: 24-28].

W przypadku rynku ubezpieczeniowego konsumenci dostali możliwość korzystania z serwisów internetowych ubezpieczycieli, wyszukiwarek, popularnych obecnie porównywarek oraz współpracujących z nimi portali internetowych. Co więcej, zmienił się sposób likwidacji szkód oraz wyliczania składki ubezpieczeniowej. Dzięki pomocy mobilnych rzeczoznawców zwiększyła się liczba dokonywanych oględzin, co wpłynęło na to, iż sam proces likwidacji szkód stał się relatywnie szybszy i łatwiejszy [Bednarczyk i Jańska 2018: 48 -49]. Usprawnienia dotyczą także sfery metod obliczania składki ubezpieczeniowej, m.in. w ubezpieczeniach OC komunikacyjnym poprzez wprowadzenie telematyki. Pozwala ona na poznanie stylu jazdy kierowcy, w jakich godzinach korzysta z samochodu i jak o niego dba. Na podstawie tego ubezpieczyciel może 
wyliczyć optymalną składkę, a później aktualizować ją w czasie rzeczywistym, jeśli zachowanie ubezpieczonego się zmieni [Cieślik 2017: 80-83].

Kolejnym segmentem jest WealthTech. Skupia się on na inwestycjach oraz zarządzaniu majątkiem danego konsumenta. Jak w przypadku wcześniejszych segmentów, WealthTech również korzysta z internetowych kanałów dystrybucji i dedykowanych produktów, m.in. wirtualnego doradztwa, które podobnie jak porównywarki pomaga oszacować jaki produkt, w tym przypadku inwestycja, może być odpowiednia dla konsumenta. Jednak w przeciwieństwie do telematyki wykorzystuje dane podane przez klienta [Rogowski 2017: 55-56]. Ten segment zawiera w sobie również kryptowaluty, czyli zdecentralizowane cyfrowe waluty, które czynią swojego użytkownika anonimowym oraz technologię blockchain służącą do obliczania jej wartości poprzez zapisywanie informacji o przeprowadzanych transakcjach w sekwencjach bloków [Mazurczak 2015: 109-111].

Ostatnią część sektora FinTech stanowi RegTech. Może być on w pewien sposób traktowany jako trzon pozostałych segmentów, działając jako ich zaplecze technologiczne i regulacyjne, gdyż jego zadaniem jest zapewnianie przestrzegania regulacji. W przypadku gdy wybrana technologia nie będzie spełniać wymogów prawnych, to właśnie podmioty RegTech będą odpowiedzialne za dostosowanie ich do wymagań ustawodawcy [Manta 2018: 90]. Oprócz powyższego, do zadań RegTech należy rozwój innowacji i wspomaganie podstawowej działalności pozostałych podmiotów FinTech, m.in. poprzez ograniczanie kosztów compliance oraz współpracę z organem nadzoru i regulatorami [Pięta 2018: 250].

\section{TEORETYCZNE ASPEKTY RAM PRAWNYCH}

Sektor FinTech jest rozbudowany, a przy tym głęboko zintegrowany z tradycyjnym rynkiem finansowym. Świadectwem tego jest chociażby fakt, iż w świadomości konsumentów bankowość internetowa jest uznawana jako jeden ze standardowych kanałów dostępu, pomimo iż sam produkt powstał dzięki wykorzystaniu technologii informatycznych. Jednak z uwagi na ich powszechne wykorzystanie, nie mogą być traktowane tako tożsame względem usług oferowanych przez licencjonowane podmioty, takie jak banki. W związku z powyższym, powstaje potrzeba wprowadzenia nowych, dokładniejszych przepisów prawa, zarówno krajowych jak i globalnych, m.in. za pośrednictwem dyrektyw Unii Europejskiej. Jednak większą rolę odgrywają regulacje międzynarodowe, gdyż wprowadzają pewną presję względem organizacji jako ogółu, a tym samym gwarantują zmianę dotychczasowej strategii podmiotu.

Dla porównania, w przypadku gdy ustawodawstwo danego kraju jest dla danej instytucji mniej korzystne i będzie wymuszać działania mające lepiej 
chronić konsumentów, istnieje większe prawdopodobieństwo, iż podmiot wprowadzi tylko zmiany lokalne, a nie globalne, ponieważ żadne międzynarodowe regulacje nie będą do tego nakłaniać.

Nauczeni doświadczeniami z ostatniego kryzysu finansowego ustawodawcy różnych krajów zdecydowali się na podjęcie szeregu działań prewencyjnych, mających uchronić rynek finansowy przed kolejną recesją. Jednym z nich było wprowadzenie nowych ram prawnych, i tak w 2007 roku zaczęło się potocznie zwane „tsunami regulacyjne”. Od początku tego okresu zostały uchwalone, m.in. Bazylea III i IV, dyrektywy CRD (Capital Requirements Regulation) II, III i IV dyrektywy PSD (Payment Services Directive) i PSD2 oraz wiele innych, z których niektóre były prawie corocznie aktualizowane. Jednak nie wszystkie aspekty działania FinTech zostały unormowane, czego dowodem jest fakt, że nadal trwają pracę nad nowymi regulacjami [Dziawgo i Dziawgo 2018: 12-13].

Tak częste zmiany prawa sprawiły, iż potrzebne stało się narzędzie do oceniania jego potencjalnych skutków. W tym celu Unia Europejska zaczęła wykorzystywać metodę RIA (regulatory impact assessment). Polega ona na wprowadzeniu do standardowego procesu legislacyjnego również elementu konsultacji społecznych i konsultacji do oceny zasadności oraz jakości implementowanych przepisów prawa. $\mathrm{W}$ ramach tego zostały powołane instytucje mające nadzorować procesy legislacyjne i tworzone projekty mające je usprawnić, jednak do najistotniejszych z punktu widzenia sektora FinTech należy wymienić piaskownice regulacyjne (regulatory sandbox). Schemat ich działania polega na stworzeniu przez regulatora lub danego organu nadzorczego bezpiecznego środowiska testowego, w którym można testować innowacje. Istotne jest to, że organizator odgórnie decyduje o warunkach testowych - środowisku, czasie badania, grupie uczestników i sprawuje nadzór nad testowaniem. W zależności od projektu instytucja może się również zdecydować na powołanie grupy podmiotów, które także będą sprawować nadzór nad testerami. W takim wypadku, w skład nowoutworzonej grupy mogą wchodzić inne podmioty nadzorcze lub instytucje finansowe, działające od dłuższego czasu na rynku i wykorzystujące innowacje w działalności. Sprawia to, że piaskownica ma formalny charakter oraz służy przede wszystkim do badania nowych pomysłów. Dodatkowo podmioty, których produkty pozytywnie przejdą wszystkie testy, będą mogły w trakcie trwania projektu ubiegać się o wydanie licencji od organu nadzorczego. Jednak nie jest to jedyny cel piaskownicy. Oprócz oceny zasadności danego pomysłu i testerów, projekt ma także na celu zweryfikować, czy obecne regulacje prawne są gotowe na wprowadzenie danego produktu na rynek oraz jakie ewentualne luki prawne mogą powstać. Pozwala to na trafne zidentyfikowanie barier regulacyjnych, przy jednoczesnym ograniczeniu kosztów, które ponosi pomysłodawca przy wprowadzaniu innowacji na rynek [Marchewka-Bartkowiak 2018: 138-142]. 


\section{DYREKTYWA PSD2 JAKO PRZYKŁAD REGULACJI UNIJNYCH}

Wśród najistotniejszych regulacji unijnych uchwalonych w przeciągu ostatnich lat należy wymienić Dyrektywę Parlamentu Europejskiego i Rady (UE) 2015/2366 z dnia 25 listopada 2015 r. w sprawie usług płatniczych w ramach rynku wewnętrznego zwaną w skrócie PSD2 (Payment Services Directive 2). Zastępuje ona wcześniejszą dyrektywę PSDl z dnia 13 listopada 2007 r. a wprowadzone przez nią zmiany mają na celu uregulować wcześniej obszary wcześniej nie objęte przez PSD1. Tworząc nową dyrektywę ustawodawca unijny chciał przede wszystkim dostosować regulacje rynku finansowego do zachodzących na nim zmian, głównie w zakresie dokonywanych płatności oraz zapewnić konsumentom odpowiedni poziom bezpieczeństwa ${ }^{1}$.

Jedną z wprowadzanych zmian jest rozszerzenie definicji usług płatniczych o dwie pozycje. Dokładniej o usługi inicjowania płatności (payment initiation services - PIS) oraz o usługi dostępu do informacji z rachunku (account information services - AIS) [Dyrektywa Parlamentu Europejskiego i Rady (UE) 2015/2366 z dnia 25 listopada 2015 r..., załącznik nr 1]. Ustawodawca wyróżnił również nową kategorię podmiotów na rynku finansowym - dostawcę usług płatniczych będącego osobą trzecią (third party payment provider - TPP), która wykonuje usługi AIS i PIS. Ten typ podmiotów funkcjonuje jako pośrednik między bankiem, innymi dostawcami usług płatniczych oraz konsumentem. Wprowadzenie pojęcia tych jednostek obrazuje, jak zmieniło się podejście regulatorów unijnych do podmiotów unijnych i świadczy o tym, że zostały zaakceptowane jako uczestnicy rynku finansowego [Ferrarini 2017, dostęp 21.07.2019: 138-139].

Funkcjonowanie usług inicjowania płatności opiera się na udzieleniu dostępu podmiotowi trzeciemu do rachunku zleceniodawcy płatności. Uzyskany dostęp ma charakter krótkoterminowy i służy tylko do sprawdzenia aktualnego stanu środków płatnika. W przypadku gdy kwota na rachunku będzie wystarczająca TPP zainicjuje płatność i wyśle do właściciela rachunku informację o jej wykonaniu. $\mathrm{W}$ przeciwnym razie płatność nie zostanie zrealizowana, a płatnik zostanie poinformowany o jej odrzuceniu. Drugi typ usług - AIS, również polega na udzieleniu TPP dostępu do rachunku klienta. Jednak w tym wypadku informacje nie są wykorzystywane do weryfikacji usługi, tylko są bezpośrednio udzielane konsumentowi. Przedstawiane informacje mają formę zagregowaną oraz pokazują aktualny stan wszystkich posiadanych przez klienta rachunkach płatniczych. Ważną informacją dla konsumentów jest to, że obie powyższe usłu-

${ }^{1}$ Dyrektywa Parlamentu Europejskiego i Rady (UE) 2015/2366 z dnia 25 listopada 2015 r. w sprawie usług płatniczych w ramach rynku wewnętrznego, zmieniająca dyrektywy 2002/65/WE, 2009/110/WE, 2013/36/UE i rozporządzenie (UE) nr 1093/2010 oraz uchylająca dyrektywę 2007/64/WE, Motywy nr 1, 3, 5, 6 . 
gi są traktowane jako usługi pomocnicze wobec właściwych usług płatniczych. Za te uznaje się operacje, podczas których dochodzi do realnego transferu środków pieniężnych między rachunkami. Ma to zagwarantować konsumentom dodatkową ochronę ich środków, w szczególności przy realizacji usług typu PIS [Czugan i Rogowski 2017: 29].

Dyrektywa określa również, jakie wymogi licencyjne muszą spełnić $T P P$. Podmioty, które są zainteresowane świadczeniem usług typu PIS mają obowiązek uzyskania licencji na prowadzenie działalności. Temu obowiązkowi nie podlegają jednostki świadczące usługi $A I S$, ale są wciąż zobowiązane do zarejestrowania swojej działalności [Dyrektywa Parlamentu Europejskiego i Rady (UE) 2015/2366 z dnia 25 listopada 2015 r..., art. 33]. Na podmioty trzecie są też nakładane stosunkowo mniejsze wymagania, niż w przypadku pozostałych uczestników rynku, m.in. wysokość kapitału własnego. Jednostki inicjujące płatności muszą posiadać przez całość działalności kapitał własny na poziomie przynajmniej 50 tys. euro. Dla porównania, instytucje świadczące bardziej tradycyjne usługi płatnicze są zobligowane do posiadania 125 tys. euro kapitału własnego [Dyrektywa Parlamentu Europejskiego i Rady (UE) 2015/2366 z dnia 25 listopada 2015 r..., art. 7, ust. b i c].

Zmianom na korzyść konsumentów uległy limity odpowiedzialności płatników za nieautoryzowane transakcje płatnicze. Dotychczas limit odpowiedzialności wynosił 150 euro, ale wraz z wprowadzeniem PSD2 został zmniejszony do 50 euro, a w wypadku gdy instytucja świadcząca usługi płatnicze nie zachowała należytego poziomu zabezpieczeń i płatnik nie dokonał czynu niedozwolonego, wówczas nie ponosi on żadnej odpowiedzialności. Jednak w standardowych transakcjach należy pamiętać, iż limit nie ma zastosowania, jeśli nie zostaną spełnione następujące warunki [Dyrektywa Parlamentu Europejskiego i Rady (UE) 2015/2366 z dnia 25 listopada 2015 r..., art. 74, ust. 1 i 2]:

- Przed zleceniem płatności płatnik nie mógł stwierdzić, iż posiadany przez niego instrument płatniczy został utracony, skradziony lub przywłaszczony, ale żeby ten warunek miał zastosowanie płatnik nie może mieć nieuczciwych zamiarów;

- Utrata instrumentu wyniknęła z działań lub ich braku ze strony innych jednostek, niezależnych od płatnika lub ich pracowników, które uczestniczyły w przeprowadzeniu transakcji - pracownika, agenta, oddziału instytucji, która działa jako dostawca usług płatniczych lub jednostki outsourcujacej.

Akt prawny porusza również aspekt bezpieczeństwa środków pieniężnych konsumenta. Jeśli zostanie przeprowadzona transakcja, która według płatnika nie została autoryzowana przez niego lub została wykonana w sposób nieprawidłowy, to obowiązkiem jednostki świadczącej usługi płatnicze będzie udowodnienie, iż operacja otrzymała odpowiednią autoryzację oraz została należycie przeprowadzona [Dyrektywa Parlamentu Europejskiego i Rady (UE) 2015/2366 
z dnia 25 listopada 2015 r..., art. 72, ust. 1]. W przypadku, gdy konsument korzysta ze swojego rachunku przez Internet, zleca elektroniczne transakcje płatnicze lub przeprowadza operacje z poziomu kanału zdalnego, który ze swojej natury jest narażony na liczne oszustwa i nadużycia, płatnik jest zobligowany do korzystania z silnego uwierzytelniania klienta [Dyrektywa Parlamentu Europejskiego i Rady (UE) 2015/2366 z dnia 25 listopada 2015 r..., art. 97, ust. 1]. Tym pojęciem regulator określił typ autoryzacji, który wykorzystuje co najmniej dwa elementy zakwalifikowane do poniższych kategorii [Dyrektywa Parlamentu Europejskiego i Rady (UE) 2015/2366 z dnia 25 listopada 2015 r..., art. 4, ust. 30]:

- Wiedza - zasób informacji, który powinien być znany tylko płatnikowi;

- Posiadanie - związane z rzeczami posiadanymi przez konsumenta, przykładowo tokenem;

- Cechy klienta - wykorzystujące cechy przypisane bezpośrednio do użytkownika, m.in. linie papilarne, które mogą być stosowane w weryfikacji biometrycznej.

Dodatkowo wybrane elementy powinny być niezależne od siebie, czyli naruszenie jednego nie ma negatywnych skutków na pozostałe, jak ma to miejsce w przypadku daty urodzenia i numeru PESEL. Ten warunek ma zagwarantować dodatkową ochronę poufności integralnych danych.

Skutkiem wdrożenia dyrektywy było ustalenie Regulacyjnych Standardów Technicznych (RTS), czyli pewnych reguł, które mają zastosowanie w relacjach między bankami a podmiotami trzecimi dostarczającymi usługi płatnicze. Zgodnie $\mathrm{z}$ ogólnymi zasadami, banki muszą zagwarantować podmiotom TPP dostęp do informacji o rachunkach. Powinien być on udzielany przez dedykowany dostęp (Application Programming Interface - API), a w przypadku gdy taki kanał nie jest dostępny to przez interfejs, $\mathrm{z}$ którego korzystają klienci instytucji [Grzywacz i Jagodzińska-Komar 2018: 162-163]. Bez względu na wybrany kanał dostępu, banki muszą zagwarantować podmiotom trzecim taki sam standard dostępności i funkcjonalności. Pozwoli to na zapewnienie jak najwyższej jakości uzyskiwanych informacji. Oprócz tego, został nałożony na banki zakaz celowego ingerowania w usługi $A I S$ i PIS. Przez takie działania rozumiane są wszystkie operacje, których celem jest utrudnianie działalności podmiotów trzecich, m.in. obowiązku redirection. Dodatkowo oprócz jednego kanału dostępu instytucje finansowe są zobligowane do przedstawienia alternatyw, z których $T P P$ będą mogły natychmiast skorzystać, jeśli pojawi się problem z podstawowym źródłem dostępu [Gałązka 2017, dostęp 20.07.2019].

Postulaty zawarte $\mathrm{w}$ dyrektywie są niezwykle istotne $\mathrm{z}$ punktu widzenia zarówno banków, jak i podmiotów FinTech, ponieważ wprowadzają potrzebę współpracy. $Z$ jednej strony, banki potrzebują wprowadzić wyższy poziom bezpieczeństwa swoich konsumentów, m.in. poprzez wprowadzenie silnej autoryza- 
cji transakcji, jednak aby to zrobić wymagają one wsparcia ze strony innowacyjnych podmiotów. W konsekwencji umożliwia im to wzbogacenie dostępnych metod zabezpieczeń o m.in. biometrię odcisku palca lub rozpoznawanie twarzy. Z drugiej strony, część działalności podmiotów FinTech w zakresie realizacji płatności została zakwalifikowana, jako poboczna względem tej oferowanej przez banki. Sprawia to, że aby móc funkcjonować na rynku część innowacyjnych podmiotów będzie zmuszona do zawarcia współpracy. Niemniej jednak wprowadzenie dyrektywy w pewien sposób otworzyło drogę jednostkom FinTech i pozwoliło im na znalezienie swojego miejsca na rynku finansowym [Grzywacz i Jagodzińska-Komar 2018: 167-168].

\section{KRAJOWE REGULACJE PRAWNE}

$\mathrm{W}$ Polsce ramy prawne mogą być tworzone zgodnie $\mathrm{z}$ jedną $\mathrm{z}$ dwóch dróg - przez uchwalanie nowych ustaw lub przez popularniejsze zmienianie już obowiązujących przepisów prawa. Jednocześnie należy nadmienić, iż z uwagi na dynamikę podmiotów FinTech ustawodawcy decydują się na wprowadzenie regulacji o charakterze przedmiotowym, czyli odnoszące się do obszaru aktywności samego podmiotu. $Z$ uwagi na to, iż innowacje technologiczne są wprowadzane w różnych podsektorach rynku finansowego, przepisy prawa, które go obejmują, także są rozproszone na poszczególne ustawy, a wśród najistotniejszych z nich należy wymienić [Czugan i Rogowski 2017: 29]:

- Ustawę z dnia 19 sierpnia 2011 r. o usługach płatniczych;

- Ustawę z dnia 29 sierpnia 1997 r. - Prawo bankowe;

- Ustawę z dnia 11 września 2015 r. o działalności ubezpieczeniowej i reasekuracyjnej;

- Ustawę z dnia 27 maja 2004 r. o funduszach inwestycyjnych i zarządzaniu alternatywnymi funduszami inwestycyjnymi;

- Ustawę z dnia 10 maja 2018 r. o ochronie danych osobowych oraz wcześniejszą ustawę z dnia 29 sierpnia 1997 r.;

- Ustawę z dnia 23 kwietnia 1964 r. - Kodeks cywilny.

Ustawa o usługach płatniczych reguluje kwestie związane z pieniądzem elektronicznym. Chociaż nie wymienia on wprost walut cyfrowych w swoim słowniczku pojęciowym, to można znaleźć typy usługi, które teoretycznie mogą je wykorzystywać, m.in. wydawanie instrumentów płatniczych. Biorąc pod uwagę to, jak ogólnie zostały zdefiniowane zarówno same instrumenty płatnicze, jak i zlecenia płatnicze, do których są wykorzystywane, nie można wykluczyć możliwości stosowania tej ustawy w kontekście kryptowalut. Tym bardziej, iż słownik pojęciowy uwzględnia instytucje pieniądza elektronicznego [Ustawa z dnia 19 sierpnia 2011 r..., Dz.U. 2011, poz. 1175, art. 3 ust. 1, art. 2 ust. 10, 
10a i 36]. Ważną informacją jest również fakt, że znowelizowana wersja ustawy wprowadza postulaty zawarte w dyrektywie PSD2. Oznacza to, że niektóre pojęcia, takie jak przykładowo środki pieniężne, powinny być rozumiane zgodnie $\mathrm{z}$ definicjami zawartymi w dyrektywie, która w tym przypadku uwzględnia pieniądze elektroniczne [Dyrektywa Parlamentu Europejskiego i Rady (UE) 2015/2366 z dnia 25 listopada 2015 r..., art. 4 ust. 25]. Kolejne odniesienia do walut cyfrowych można znaleźć w ustawie o funduszach inwestycyjnych i zarządzaniu alternatywnymi funduszami inwestycyjnymi. Jednak tutaj nie odnoszą się do samego używania ich jako środków płatniczych, tylko do inwestowania w nie w celach zarobkowych [Rogowski 2017: 62].

Chociaż regulator nie określa wprost kwestii związanych z ustalaniem umów, zarówno w bankowości mobilnej, jak i elektronicznej, to nie można powiedzieć, że nie zostały one poruszone. W ustawie znajdują się liczne odniesienia wskazujące na to, że banki będą akceptowały dokumentację w postaci elektronicznej [Ustawa z dnia 29 sierpnia 1997 r..., Dz.U. 2018, poz. 2187, art. 4 ust. 1 art. 5, art. 7]. Te same zmiany w procesie dokumentacji wprowadza nowelizacja Kodeksu Cywilnego. Dopuszcza ona możliwość stosowania elektronicznej formy dokumentów oraz stosowania podpisu elektronicznego zamiast standardowej wersji papierowej [Ustawa z dnia 23 kwietnia 1964 r..., Dz.U. 2018, poz. 1025, art. 78].

Kwestie związane $\mathrm{z}$ ochroną i przetwarzaniem danych osobowych zostały poruszone $\mathrm{w}$ większości wyżej wymienionych ustaw. W świetle dotychczas obowiązującego prawa, podmioty zajmujące się administracją danych były zobligowane do uzyskania zgody na ich przetwarzanie, pod warunkiem iż w umowie, zgodnie z którą wykonują tę usługę nie było to odgórnie wymagane. Te same wymogi miały zastosowanie $\mathrm{w}$ przypadku analizy danych wrażliwych, czyli takiej kategorii danych, które z racji na swój charakter wymagają dodatkowej ochrony. Jeśli podmiot zainteresowany wyraził zgodę na ich przetwarzanie, to musi mieć to potwierdzenie na piśmie [Ustawa z dnia 29 sierpnia $1997 \mathrm{r}$..., Dz.U. 2016, poz. 922, art. 23, ust. 1, art. 27]. Zbliżone wymogi prawne są przedstawione w ustawie o działalności ubezpieczeniowej i regulacyjnej, w kontekście weryfikacji danych medycznych. Ubezpieczyciele chcący potwierdzić u lekarza zebrane informacje, muszą wpierw uzyskać od ubezpieczonego pisemne oświadczenie [Ustawa z dnia 11 września 2015 r..., Dz.U. 2018, poz. 999, art. 38 ust. 6]. Regulator wyłączył również możliwość wydawania zautomatyzowanych decyzji na podstawie profilowania. Wyjątkiem są sytuacje, w których konsument wcześniej wyraził zgodę na to, przykładowo podczas oceny ryzyka kredytowego [Ustawa z dnia 29 sierpnia $1997 \mathrm{r}$ o ochronie ..., art. 26a].

Uregulowana została również możliwość korzystania $\mathrm{z}$ zewnętrznych przedsiębiorstw do outsourcowania części procesów przez banki [Ustawa z dnia 29 sierpnia 1997 r. - Prawo..., art. 6a. ust. 1] oraz ubezpieczycieli [Ustawa 
z dnia 11 września 2015 r..., art. 73, ust. 1-3]. W przypadku gdy podmiot przetwarzający dane osobowe na zlecenie instytucji finansowej będzie je transferował poza Europejski Obszar Gospodarczy, ponieważ przykładowo ma siedzibę w kraju trzeciej, to podmioty korzystające $\mathrm{z}$ ich usług będą musiały liczyć się z wymogiem przedstawienia dodatkowej podstawy prawnej [Ustawa $\mathrm{z}$ dnia 29 sierpnia 1997 r. o ochronie..., art. 47]. Oprócz tego, banki chcące korzystać z usług zagranicznych podmiotów muszą wpierw uzyskać zgodę od KNF [Ustawa z dnia 29 sierpnia 1997 r. - Prawo..., art. 6d ust. 1]. Podstawą do przekazania podmiotowi trzeciemu danych do analizy jest umowa o powierzenie, a jeśli nie zostało $\mathrm{w}$ niej inaczej określone, to podczas trwania umowy administrator staje się odpowiedzialny za przestrzeganie zgodności prac z obowiązującymi ramami prawnymi [Ustawa z dnia 29 sierpnia 1997 r. o ochronie..., art. 31, art. 36-39].

W trosce o zasadność oraz jakość wprowadzanych regulacji, KNF prowadzi szereg inicjatyw związanych z sektorem FinTech w Polsce. Jedną z nich jest powołanie pod koniec 2016 roku specjalnej komórki dedykowanej rozwojowi innowacyjnych podmiotów. Zespół roboczy ds. rozwoju innowacji finansowych (FinTech) powstał w wyniku współpracy Ministerstwa Finansów, Ministerstwa Rozwoju oraz Komisji Nadzoru Finansowego, która koordynuje jego pracę. Podstawowym celem tegoż zespołu jest identyfikacja wszelkich barier rozwoju sektora oraz opracowywanie ich rozwiązań. Rok po powołaniu komórki, w listopadzie 2017, został opracowany raport z prac Zespołu, w którym przedstawiono aż osiemdziesiąt pięć barier rozwoju sektora, wraz z proponowanymi rozwiązaniami oraz stopniem prac w zakresie ich likwidacji. Spośród nich trzy zostały już usunięte, a nad aż pięćdziesięcioma ośmioma prowadzone są prace [KNF, 2017, dostęp 21.07.2019: 33-123].

Polska podejmuje jednocześnie działania mające na celu wsparcie rodzimych innowacji. W tym celu wprowadziła projekt Piaskownicy regulacyjnej KNF. Podobnie do piaskownic organizowanych przez inne kraje, pozwoliła na sprawdzenie swoich pomysłów w środowisku testowym. Uczestnikami projektu moga być zarówno podmioty nadzorowane jak i start-upy, które oprócz KNF mogą także oczekiwać wsparcia od operatorów piaskownicy, czyli instytucji, które zgłosiły się do wsparcia projektu. W przypadku Piaskownicy regulacyjnej takich podmiotów jest osiem, z czego większość to banki - PKO Bank Polski S.A., Alior Bank S.A., Bank Pekao S.A., Bank Handlowy w Warszawie S.A. oraz Bank BGŻ BNP Paribas S.A. Pozostałe trzy podmioty to Huge Thing Sp. z o.o., D-RAFT S.A. oraz Fundacja Rozwoju Przedsiębiorczości BusinessCaddy. Ich najważniejszym zadaniem było stworzenie specjalnej przestrzeni do zorganizowania projektu oraz weryfikacja potencjalnych uczestników, ponieważ to właśnie operatorzy będą wspierać wprowadzenie produktu na rynek. Zgłoszenia są oceniane przez operatorów, a następnie wysłane KNF, który po- 
dejmuje ostateczną decyzję o uczestnictwie w projekcie oraz ustala plan, warunki środowiska testowego oraz indywidualne wymogi licencyjne [Folwarski 2018: 132-133].

Kolejnym sukcesem KNF jest organizacja projektu Innovation Hub dedykowanego rozwojowi innowacyjnych podmiotów. W ramach tej inicjatywy zainteresowane przedsiębiorstwa mają możliwość uzyskania ze strony KNF wsparcia regulacyjno-prawnego oraz mogą uzyskać wszystkie niezbędne informacje o sposobie i warunkach uzyskania licencji na rynku finansowym. Zespół powołany przez KNF zajmuje się również wsparciem krajowego regulatora, zarówno w dostosowywaniu prawa do regulacji unijnych, jak i tworzeniu przepisów, mających zastosowanie tylko na polskim rynku. Przykładem takich działań jest wsparcie Ministerstwa Finansów w tworzeniu projektu ustawy o usługach płatniczych w celu implementacji postulatów dyrektywy PSD2. Wtedy właśnie Zespół zaproponował wprowadzenie w polskich przepisach prawnych nowego typu jednostki gospodarczej - małych instytucji płatniczych (MIP). Jednostki zainteresowane funkcjonowaniem jako MIP będą zobligowane do zarejestrowania swojej działalności w KNF. Wtedy też zostaną na nie nałożone określone wymogi do spełnienia, jednak będą one relatywnie niższe niż w przypadku wymagań krajowych instytucji płatniczych. Jednostka po uzyskaniu odpowiedniej licencji, będzie mogła zacząć swoją działalność, która nie musi być ograniczona jedynie do świadczenia usług płatniczych, ale będzie zobowiązana do funkcjonowania tylko i wyłącznie wewnątrz obrębu kraju. Podczas prowadzenia działalności jednostka będzie również musiała na bieżąco monitorować swój obrót, ponieważ jeśli przekroczy on 1500000 euro miesięcznie, to podmiot nie będzie mógł od następnego miesiąca działać jako MIP [Kabza i in. 2019: 111-114].

Widoczne są też działania KNF w kontekście kryptowalut. Komisja niejednokrotnie przestrzega konsumentów przez jednostkami, które zostały wpisane na „Listę ostrzeżeń publicznych Komisji Nadzoru Finansowego". W komunikacie odnośnie walut cyfrowych KNF ostrzega, że instytucje, które nimi obracają nie są licencjonowane, a w przypadku gdy dany podmiot stanie się niewypłacalny, środki konsumentów nie będą w żaden sposób prawnie chronione. Organ nadzorczy wyjaśnił też schemat działania kryptowalut, żeby podkreślić jego odrębność od innych produktów pośrednio objętych ochroną [www1].

\section{KONCEPCJA LAW AS A RULE VERSUS LAW AS A CODE}

Alternatywnym nurtem do działań legislacyjnych jest koncepcja law as a rule versus law as a code. Powstała ona na bazie przemyśleń, zgodnie z którymi kultura $\mathrm{i}$ jednostki instytucjonalne nie mogą działać niezależnie od siebie $\mathrm{i}$ jedno z nich wpływa na drugie. Powoduje to, że skuteczność działania podmiotów jest 
w pewnym stopniu zależna od otoczenia, w którym funkcjonuje, a w efekcie czynniki kulturowe wpływają na to jakie jest tempo i kierunek rozwoju kulturowego na danym obszarze. W efekcie rządy krajów cechują się pewnym stopniem nieskuteczności w zakresie wprowadzania i egzekwowania prawa [Szpringer 2017, dostęp: 21.07.2019: 7-8].

Metodą na wyeliminowanie tej, w pewien sposób przymusowej nieskuteczności, jest wspieranie już obowiązującego prawa lub jego stopniowe wypieranie przez oprogramowanie. Zaletą takiego podejścia jest fakt, iż w przeciwieństwie do prawa zawartego w aktach prawnych, reguły umieszczone w kodzie oprogramowania muszą być automatycznie przestrzegane. Dzieje się tak, ponieważ ich wprowadzenie ogranicza możliwości danego oprogramowania i tym samym przykładowy użytkownik takiego programu nie będzie mógł wykonać części operacji, które są w świetle prawa uznane za zakazane, ponieważ oprogramowanie, z którego korzysta nie pozwoli mu na to, ponieważ nie posiada funkcji wykonania takich komend. Chociaż podobnie jak regulacje, programy nie są w stanie zagwarantować, że wszyscy użytkownicy będą stosować się do ustalonych reguł, gdyż zawsze znajdą się osoby skłonne do ingerowania w kod źródłowy, aby osiągnąć swój cel, to jednak pozwala to teoretycznie znacznie zmniejszyć odsetek osób działających wbrew prawu [Szpringer 2017, dostęp: 21.07.2019: 8-9].

Jest to spowodowane przez fakt, iż korzystając $\mathrm{z}$ oprogramowania system nadzoruje aktywność swoich użytkowników oraz reaguje w chwili, w której zostaną wykryte wszelkie nieprawidłowości. Istotny jest też sam charakter reguł zapisanych w kodzie. W porównaniu do prawa zawartego w aktach prawnych, są one bardziej surowe i dokładniej sprecyzowane. Jest to spowodowane tym, że podczas tworzenia oprogramowania jego twórca musi określić pulę dozwolonych i niedozwolonych czynności, w oparciu o które tworzony jest kod. W ten sposób wszyscy użytkownicy muszą przestrzegać jednej narzuconej interpretacji, co zwykle nie ma miejsca przy tradycyjnych przepisach prawa, które często są tworzone w dość ogólny sposób pozwalający na więcej niż jedną interpretację. Z jednej strony sprawia to, że przepisy prawa są relatywnie dłużej aktualne. Przykładowo, jeśli w ustawie dotykającej kwestii instrumentów płatniczych zostanie napisane, iż dotyczy wszystkich środków zdolnych do wykonywania transakcji, to teoretycznie może objąć produkty finansowe, które jeszcze nie powstały, a które będą mogły realizować tę funkcję. Z drugiej strony, przepisy prawa są relatywnie bardziej przyjazne, gdyż dopuszczają możliwość odwołania się od nich lub złożenia wniosku o indywidualną interpretację podatkową. Niewątpliwą wadą stosowania koncepcji law as a rule versus law as a code, jest możliwość wystąpienia błędów powodujących nieprawidłowe egzekwowanie zasad zapisanych w kodzie, jednak jego twórcy podejmują działania mające ograniczyć to ryzyko. Prowadzone są również prace w zakresie wykorzystania 
sztucznej inteligencji. Pozwala ona na stworzenie „uczącego się” programowania, które będzie wykorzystywało informacje z zewnętrznych źródeł. Teoretycznie umożliwi to stworzenie systemu, który pozwoli na dynamiczne zmiany obowiązujących reguł i dzięki temu relatywnie dokładniejsze wykonanie zadania. Jednak nie jest to rozwiązanie bez wad i nadal można je rozwijać [Hassan i De Filippi 2017: 89-90].

\section{PODSUMOWANIE}

Sektor FinTech jest niezwykle rozległy i głęboko zintegrowany z tradycyjnym rynkiem finansowym, do tego stopnia, iż niejednokrotnie granice między nimi są zacierane. Jest to skutek wszechobecnej cyfryzacji oraz przyzwyczajenia do korzystania z Internetu. Obecnie dostęp do kanałów internetowych jest tak powszechny, iż wielu konsumentów, szczególnie młodych, nie wyobraża sobie produktów finansowych bez nich, tak jak obsługi konta w inny sposób niż przez portal bankowości internetowej. Jeszcze dobitniej świadczy to o tym, iż dzisiejszy rynek finansowy nie mógłby istnieć bez stałego dopływu innowacji oraz zmian jakie wprowadzają. Jednocześnie dzięki dynamice sektora technologii finansowych rynek jest poddawany ciągłym zmianom. Sprawia to, że powstają usługi wcześniej nie oferowane przez podmioty finansowe, a w konsekwencji nie uwzględnione w regulacjach dotyczących tychże podmiotów. W efekcie tego powstają luki prawne, które są często wykorzystywane przez innowacyjne podmioty, co pośrednio przyczynia się do kreowania ryzyka dla pozostałych uczestników rynku. Świadczy to o tym, iż obecne regulacje nie obejmują w pełni całości sektora, a tym samym nie zapewniają należytej ochrony jego uczestnikom. Chcąc temu zaradzić, różni ustawodawcy podejmują działania mające objąć sektor FinTech ramami prawnymi, zarówno poprzez stworzenie nowych aktów prawnych, jak i aktualizowanie obecnych. Przykładem drugiego podejścia jest unijna dyrektywa PSD2 o charakterze międzynarodowym, która obejmuje szerokorozumiane transakcje płatnicze. Wprowadzone w niej postulaty uznają działalność FinTech i tworzą potrzebę współpracy z bankami. Pokazuje to, że chociaż od lat stosowane są różnego rodzaju usługi płatnicze, to nadal ustawodawcy potrafią zidentyfikować coraz to nowe problemy. Wśród krajowych ustaw istotną rolę odgrywa ustawa o usługach płatniczych, która została sformułowana tak, aby teoretycznie dopuszczać kryptowaluty do puli uznanych instrumentów płatniczych. Jednocześnie rozwija się alternatywne podejście do ram prawnych, zgodnie z którym oprogramowanie może wymusić na uczestnikach rynku przestrzeganie obwiązującego prawa, bez potrzeby wprowadzania kolejnych aktów prawnych. Jednak dopiero z czasem będzie można ocenić, czy ta koncepcja sprawdzi się lepiej niż tradycyjne prawodawstwo. 


\section{BIBLIOGRAFIA}

Baszyński A., 2016, Zmiana technologiczna jako determinanta struktury konkurencyjnej rynku uslug bankowych, „Zeszyty Naukowe Wydziału Zamiejscowego w Chorzowie Wyższej Szkoły Bankowej w Poznaniu, Finanse dziś i jutro - szanse, wyzwania i zagrożenia", nr 18.

Bednarczyk TH., Jańska A., 2018, Innowacje produktowe i procesowe w obszarze ubezpieczeń majątkowych dla osób fizycznych, Uniwersytet Marii Curie-Skłodowskiej w Lublinie, „Annales Universitatis Mariae Curie-Skłodowska, sectio H - Oeconomia”, vol 53, no 3.

Cieślik B., 2017, Zastosowania telematyki w ubezpieczeniach komunikacyjnych, „Roczniki Kolegium Analiz Ekonomicznych", nr 47.

Czugan M., Rogowski W. (red.), 2017, Regulacje finansowe. FinTech - nowe instrumenty finansowe - resolution, Wydawnictwo C.H.Beck, Warszawa.

Dyrektywa Parlamentu Europejskiego i Rady (UE) 2015/2366 z dnia 25 listopada 2015 r. w sprawie usług płatniczych $w$ ramach rynku wewnętrznego, zmieniająca dyrektywy 2002/65/WE, 2009/110/WE, 2013/36/UE i rozporządzenie (UE) nr 1093/2010 oraz uchylająca dyrektywę 2007/64/WE.

Dziawgo D., Dziawgo L., 2018, Regulacje rynku finansowego w Polsce. Equilibrium vs. inwersja, „Nauki o Finansach”, nr 4(23).

Ferrarini G., 2017, Regulating FinTech: Crowdfunding and Beyond, European Economy - Banks, „Regulation, and the Real Sector”, http://european-economy.eu/wp-content/uploads/2018/ 01/EE_2.2017-2.pdf [dostęp 21.07.2019].

Folwarski M., 2018, Sektor FinTech na europejskim rynku ustug bankowych. Wyzwania konkurencyjne i regulacyjne, Wydawnictwo Poltext, Warszawa.

Gałązka P., 2017, Komisja Europejska opublikowała dzisiaj standardy techniczne (RTS) do dyrektywy $P S D \quad I I, \quad$ https://alebank.pl/komisja-europejska-opublikowala-dzisiaj-standardytechniczne=-rts-do-dyrektywy-psd-ii/?id236100\&catid=18911 [dostęp 20.07.2019].

Grzywacz J., Jagodzińska-Komar E., 2018, Rola banków i sektora FinTech w świetle implementacji dyrektywy PSD2, Kwartalnik Kolegium Ekonomiczno-Społecznego „Studia i Prace”, nr 2.

Harasim J., Mitręga-Niestrój K., 2018, FinTech - dylematy definicyjne i determinanty rozwoju, „Prace Naukowe Uniwersytetu Ekonomicznego we Wrocławiu”, nr 531.

Hassan S., De Filippi P., 2017, The Expansion of Algorithmic Governance: From Code is Law to Law is Code, „Field Actions Science Reports: The Journal of Field Actions”, special issue 17: Artificial Intelligence and Robotics in the City.

Kabza M., Gąsiorkiewicz L., Monkiewicz J. (red.), 2019, Ochrona konsumentów ustug finansowych FinTech, Wyzwania współczesnych rynków finansowych, Warszawa.

KNF, 2017, Raport z prac Zespołu roboczego ds. rozwoju innowacji finansowych (FinTech), https://www.knf.gov.pl/knf/pl/komponenty/img/Raport_KNF_11_2017_60290.pdf [dostęp: 21.07.2019].

Manta O., 2018, Financial technologies (FinTech), instruments, mechanisms and financial products, ,Internal Auditing \& Risk Management”, vol. 4(52).

Marchewka-Bartkowiak K., 2018, Nowe rozwiazania regulacyjne - RIA, sandbox, compliance, RegTech-w świetle procesu ,inflacja prawa finansowego", Studia BAS 1.

Mazurczak K., 2015, Anonimowe płatności internetowe wykorzystywane w cyberprzestępczości. Istota kryptowaluty Bitcoin, Czasopismo Uniwersytetu Przyrodniczo-Humanistycznego w Siedlcach, „De Securitate et Defensione - O Bezpieczeństwie i Obronności”, nr 2(1).

Micu A., Micu I., 2016, Financial Technology (FinTech) and its Implementation on the Romanian Non-Banking Capital Market, „SEA - Practical Application of Science”, vol. IV, no 2(11). 
Pięta A., 2018, Technologie regulacyjne szansa na obniżenie kosztów compliance, Wydawnictwo Naukowe Uniwersytetu im. Adama Mickiewicza w Poznaniu, „Ruch Prawniczy, Ekonomiczny i Socjologiczny", nr 80, z. 2.

Rogowski W., 2017, Świt wirtualnego doradztwa finansowego (robo-advisor), Czasopismo Naukowe Szkoły Głównej Handlowej w Warszawie, E-mentor, nr 4(71).

Szpringer W., 2017, Kierunki regulacji sektora fin-tech na rynku ustug finansowych, Ośrodek Badań i Analiz Systemu Finansowego Alterum, http://alterum.pl/uploaded/Szpringer\%20 full\%20last.pdf [dostęp 21.07.2019].

Szpringer W., 2017, Nowe Technologie a Sektor Finansowy: FinTech Jako Szansa i Zagrożenie, Wydawnictwo Poltext, Warszawa.

Ustawa z dnia 11 września 2015 r. o działalności ubezpieczeniowej i reasekuracyjnej (Dz.U. 2018, poz. 999).

Ustawa z dnia 19 sierpnia 2011 r. o usługach płatniczych (Dz.U. 2011, poz. 1175).

Ustawa z dnia 23 kwietnia 1964 r. - Kodeks cywilny (Dz.U. 2018, poz. 1025).

Ustawa z dnia 29 sierpnia 1997 r. - Prawo bankowe (Dz.U. 2018, poz. 2187).

Ustawa z dnia 29 sierpnia 1997 r. o ochronie danych osobowych (Dz.U. 2016, poz. 922).

[www1] https://www.knf.gov.pl/?articleId=61994\&p_id=18 [dostęp 22.07.2019].

[www2] https://www.knf.gov.pl/dla_rynku/fin_tech [dostęp 16.07.2019].

\title{
REGULATORY ENVIRONMENT OF FINTECH ON THE EXAMPLE OF PSD2 DIRECTIVE AND CHOSEN INTERNAL LAWS
}

\begin{abstract}
Nowadays in digital age many financial institutions decide to cooperate with FinTech entities. Such decision allows them to create brand new products and improve those in their pipeline. However financial market is not always ready for such innovations. With scarce and vague regulations, FinTech sector is not always able to guarantee the safety of consumers' funds and FinTech entities may in the worst case scenario not be allowed to function on financial market. Therefore all actions leading to stable regulations are deemed especially important. The aim of this article is to present the chosen regulations of this sector and assess whether they are sufficient.
\end{abstract}

Keywords: FinTech, financial regulations, PSD2, technological innovations. 